1970

\title{
The Investigation of Offences and Police Powers
}

Stanley M. Beck

Osgoode Hall Law School of York University

\section{Source Publication:}

Canadian Journal of Corrections (now Canadian Journal of Criminology and Criminal Justice).

Volume 12, Issue 3 (1970), p. 209-220.

Follow this and additional works at: https://digitalcommons.osgoode.yorku.ca/scholarly_works c) (1) $(9)$

This work is licensed under a Creative Commons Attribution-Noncommercial-No Derivative Works 4.0 License.

\section{Recommended Citation}

Beck, Stanley M. "The Investigation of Offences and Police Powers." Canadian Journal of Corrections (now Canadian Journal of Criminology and Criminal Justice) 12.3 (1970): 209-220.

This Article is brought to you for free and open access by the Faculty Scholarship at Osgoode Digital Commons. It has been accepted for inclusion in Articles \& Book Chapters by an authorized administrator of Osgoode Digital Commons. 


\title{
The Investigation of Offences and Police Powers
}

\author{
Chapter 5
}

\author{
Professor Stanley M. Beck \\ Osgoode Hall Law School \\ York University \\ Downsview, Ontario
}

It is considered bad form to criticize an author for what he did not write on the basis that, if the reviewer had been the author, he would have written a different book - or in this case a different chapter on the police. It is particularly bad form when authors explicitly state that they did not write the kind of chapter I would have liked to have seen written because they interpreted their terms of reference to exclude such a study.

The Committee's terms of reference were

to study the broad field of corrections, in its widest sense, from the initial investigation of an offence through to the final discharge of a prisoner ... including . ... arrest ...

In terms of Chapter 5, the Committee interpreted this to include only those police powers that, in its opinion, had a bearing on corrections. Generally, such matters as the structure of the Canadian police system and its internal administration, procedures for the most effective use of police manpower, and techniques of investigation were not considered to be within the terms of reference.

Such an interpretation of the terms of reference would have been unobjectionable if it had meant that the police and how they exercise their powers were not to be dealt with at all. After all, a commission on corrections is not the same thing as a commission on the administration of criminal justice. Moreover the Committee could have satisfied its terms of reference in this area by dealing with the single subject of arrest.

What the Committee did, in fact, was deal with a few internal police matters, a number of police powers and their use, and some matters of criminal procedure. All are dealt with at an almost incredible level of generalization, without the aid of any visible research, even of the library kind, and without making it clear how the "police" subjects included bear on corrections, and why those excluded do not.

Where a connection is made between the police and corrections it is on the following level:

The use of unnecessary force, sarcasm or illegal measures on the part of the police ... may increase the offender's disrespect for authority and impede his rehabilitation. Fairness may gain his cooperation.? 
Well, maybe. But surely it is the offender's view of society as a whole that matters, and the perceived fairness or unfairness of the legal system must have but a marginal effect on the behaviour of an offender or potential offender. The offender may well see in the police and the courts the living proof of all that he considers to be unfair in society, but perfect fairness in the administration of criminal justice, even if it were obtainable, would not likely change the attitudes of most offenders to society as a whole, or to the police. ${ }^{3}$ If we are talking about the young who engage in what the Committee calls "provocative behaviour", no degree of police fairness is likely to change their view of "the system". If the Committee had asked and tried to answer some basic questions about where in the social order most offenders come from, how they view society and the police and why, and what might be done to change the environment in which they grow up, it might have made an important contribution to corrections "in its widest sense".

It might be objected that there is nothing wrong with the Committee prescribing police fairness and tolerance, and the salutary effects such conduct would have. Indeed there is not, except that we did not need a distinguished Committee to work for four years to tell us that. This brings me back to my opening remarks about writing about what I think the Committee should have done rather than what it did. To stay with the instant example, we are nowhere told how an improvement in police conduct (or really, a change in police attitudes) is to be brought about, how they are to be better equipped to deal with provocative behaviour or, more importantly, what their stance toward various kinds of social disorder, apart from dealing with individual offenders, should be. The Committee contents itself with the observation that there is a need for training in this area, that it has been informed that such training is being received ${ }^{4}$ - and that is the end of the matter.

This criticism can be taken one step back. That is, the Report states in the most general terms how the police should act (fairly and with tolerance) when in contact with offenders and provocative behaviour, and recommends training to that end. What we do not know, and are not told, is how, in fact, the police in Canada are acting in the situations described. Is the use of force a common Canadian police practice? Do the police harass potential offenders, particularly juveniles? Do they treat people in low income and middle income areas differently? Is there in fact a good deal of illegal and unconscionable police conduct in Canada? How have the police handled potential and actual social disorder? Have they been unconscious contributors to such disorder? Is the attitude of the offender or potential offender significantly altered by his treatment at the hands of the police, as the Committee suggests, and as I doubt? What are the attitudes of the police towards those with whom they deal? And so on. On the evidence of Chapter 5 there has been no attempt to answer these questions through any empirical research. Indeed, as to a large part of 
Chapter 5, there is no evidence that we are dealing with the role, problems, and performance of the police in Canada today. The Committee could be generalizing about any modern police force. Whether the generalities are grounded in Canadian reality, we have no way of knowing.

The above indictment may be met by the plea of lack of time, funds and staff for such research, and this is probably the truth of the matter. (Even so, I do not accept the plea - if it was clear to the Committee that they were not to have the resources to do the job required, they would have been better advised not to deal with the subject at all.) If empirical studies in Canada were not possible, then at least a reading of the American literature was. An appreciation of the works of Wilson, LaFave, Skolnick, Gellhorn, and others ${ }^{\tilde{}}$ would surely have resulted in a more sophisticated view both of the police force as an administrative agency, and of the role and problems of the individual police officer. One hopes that such a reading would have resulted in a realization that you cannot deal with such subjects as police discretion, police-community relations, police training, police questioning, illegal searches, electronic surveillance, and the use of firearms without considering "the police system and its internal administration" - the very thing the Committee decided a priori not to consider.

The first three subject headings in Chapter 5 (pp. 39-43) deal with the police and the public. We are told that the police act

... within a framework of a legal system ... [and] remain accountable to courts of law for their conduct, and in the final analysis to the people through their elected representatives...

(the chapter is full of such ambiguous sentences. Are they descriptive or prescriptive?) Further we are told that the police cannot

carry out their duties ... unless they have the support and confidence of the public...

and that the police are

frequently subjected to criticism that is unjust and that

the police must be prepared to meet and discuss the grievances (real or alleged) of particular hostile groups. (p. 42)

What is implicit in all of this, of course, is the difficult and important question of how to subject police power to review and control, either from within or without, or through a combination of devices. ${ }^{6}$ The reality is that the police in Canada today are only answerable for their conduct, if at all, to their own internal hierarchy. The Committee itself recognizes this, particularly in its section on the admissibility of illegally obtained evidence (p. 74). Yet we are given the fatuous statements quoted above about the police and the public. The public knows what the situation is, and this, I suggest, is at the root of the problem of public confidence and 
police morale that the Report talks about. The rule of law, if it means anything, means control of official behaviour, yet the agency to which we grant the greatest power and widest discretion to interfere in our lives in the name of the law, is seen to be a law unto itself. This is the vital issue that the Committee should have dealt with, but sidestepped. Without this consideration of the structure and control of the police department, and of the function of the individual police officer within it, much, if not all, of Chapter 5 is without foundation.

The Committee sees improved police training as one of the essential requisites for creating an understanding and tolerant police force. To this end training programs are to be broadened to include social and behavioural scientists, judges, magistrates, criminologists, correctional workers and lawyers (p. 43). So the panacea of inter-disciplinary studies is to come even to the police force! Will an hour or two of lecture by a string of academics and correctional workers in the context of a six month police training course really accomplish anything? Might not any good it may do be cancelled by the ideas and attitudes of the police hierarchy who run the courses? What of the problem of putting this new "well rounded" rookie into the present police (and legal) structure? My point, once again, is simply that police training cannot be considered apart from the entire question of the structure and administration of our police departments, the role of the individual police constable, and the nature of the police function. As for the idea of cross fertilization between the police, the judiciary and correctional workers, it is an excellent one and long overdue, but its accomplishment requires something more than a statement that it would be a good idea if it were to happen.

The problem of the exercize of police discretion, and methods of channelling it, is dealt with in the narrow compass of administering a caution rather than arresting. Discretion involves such a range of questions as to how to deal with juvenile offenders, drunks, crowds, and marijuana users. Who and by what process are such decisions to be made? Is it purely an internal police matter. I suggest not, but here again we are into matters of structure, administration and accountability. Discretion also involves police procedures with respect to such matters as questioning, harassment, search, and surveillance. Here we are into problems of the police administrator and his relationship with his superiors, of the patrolman and his relationship with his inspector, of rule-making and discipline within the department, of the unwritten code of conduct common to every police force, and with the myriad of disparate functions that the modern police officer is expected to fulfill. ${ }^{6 \mathrm{a}}$ Formalized guidance and reporting procedures are required over the whole range of matters that fall within police discretion, not just in the area of administering a caution. The Committee does, however, recommend further research. (The exercize of discretion that often takes place after arrest, either through a police decision to drop or reduce a charge, or through plea bargaining with the crown 
attorney and the police, often results in the "inequality of treatment" that the Committee worries about, and is a matter that also needs clarification and guidelines.)

From the police and the public the Committee moves to a survey of police powers in Canada. As a general proposition, the Committee states its belief that a reasonable balance has been struck between the requirements of public order and the protection of civil liberties (p. 49). A number of specific powers are then singled out for examination, and recommendations for legislative change made.

The Committee slides over the problem of police questioning and the admissibility of confessions without coming to grips with the hard issues. The Committee rightly notes the comparatively free hand the Canadian judiciary gives to the police (pp. 50-51), contrasts this with the more restrictive legislative and judicial developments in England, Scotland, India (all police custody confessions are inadmissible) and the United States, but make no recommendation for change. The Committee puts its reliance on properly conducted (Report's italics) police questioning, and the provision of legal counsel.

What "properly conducted police questioning" is, or ought to be, we are not told. Surely the Committee, or its consultants, were aware of the conflict between cases like Terry, ${ }^{7}$ Starr $^{8}$ and Birza ${ }^{9}$ on the one hand and Fitton $^{10}$ and Boudreau ${ }^{11}$ on the other over the amount of cross examination that is permissible, the use of statements by other witnesses, and just how spontaneous a confession must be. And what of the problems of what is an inducement and who are persons in authority? Is the placing of a Royal Canadian Mounted Police constable in the cell next to the accused for the purposes of befriending him and getting an admission of guilt proper police conduct? Is there no inducement because the promises held out do not relate to the charge against the accused? Is the constable not a person in authority because he does not appear in uniform? All of these things happened in the Towler ${ }^{12}$ case, and the statements were admitted. Is it proper police conduct to use a Doukhobor leader to tell his followers that they would perish in Canada if they did not admit their guilt. Was the leader really not a person in authority because he was not a police officer, and were not inducements used to obtain the confessions? These were the facts in Demenoff, ${ }^{13}$ yet the British Columbia Court of Appeal admitted the confessions notwithstanding what it called "a studied use of psychological methods". Is voluntariness really the criterion for admissibility when the Supreme Court of Canada holds that it is relevant to ask the accused on the voir dire whether his statement is true? If the present law and practice was to be given the Committee's blessing, then at the least it should have laid down some guidelines for the police and the courts.

Questions that have been raised elsewhere about the social psychology of the interrogation process ${ }^{15}$ and the coercion inherent in it, find no echo in 
the Report. These questions have led some observers to the conclusion that there should be no questioning of the accused, and that police custody confessions should be inadmissible. Others have suggested that statements should only be admissible if the interrogation is recorded either on tape or on film. The Report deals with this point, but rejects the idea for the reason that there is no assurance that everything leading up to the statement will be recorded. Of course there is no assurance, but the courts and the accused would certainly have an interest in seeing that such a requirement were adhered to. If there is some suggestion here that the police would try to thwart the effectiveness of the requirement, it is hard to see why for that reason they should be allowed to question without a recording.

The difficulty of controlling police interrogation, and the coercion inherent in the process, have led to suggestions that the adversary system of criminal justice be modified to allow the questioning of an accused by a magistrate. The accused would be required to answer and would be entitled to have counsel. The proceedings, including the answers, or a refusal to answer, would become evidence at the trial. The Committee does not see, or at least does not advert to, the link between this suggestion and the control of police practices. The matter is dealt with on the basis of whether or not it would benefit law enforcement, and the conclusion (for no very good reason) is that it would not. The primary reason for rejecting the proposal is that it would remove the privilege against self-incrimination. I wonder whether the privilege is so deeply ingrained in our sense of the fairness of the criminal process as the Committee suggests. I agree that

such a long respected privilege should not be disturbed except for the clearest reasons,

but usage alone should not require us to maintain procedures that no longer have validity. I do not say that this is necessarily the case with respect to the privilege, but I do suggest that the entire adversary system of criminal justice is in need of a searching inquiry.

The power to arrest and detention on suspicion must be considered together. The Committee notes the very broad power of arrest without warrant given by s. 435 of the Code, and more particularly, by the words

... is about to commit an indictable offence...

As a result of this, and of the fact that almost every crime is an indictable offence, most arrests in Canada are made without a warrant. Whether there has been abuse of the power, and whether police administrators and the courts have laid down any standards for its exercize, we are not told. The main motive for challenging an arrest in the United States is to suppress evidence obtained as an incident to it. Without an exclusionary rule, there is no such motive in Canada. Moreover, those who are arrested, whether subsequently charged or not, are not those likely to challenge the 
police power in the courts. Thus there is little check on the use, or abuse, of the arrest power.

What we do know, however, is that most policemen think they have a power to stop and question, and to detain for interrogation. There is a good deal of evidence that such "arrests" are common practice. If legislation is to make clear, as the Report recommends, that a police officer may release a person whom he has arrested without bringing him before a justice of the peace, the way will be clear for a continuance of these arrests. Ouimet, however, argues that it would be undesirable to have a "stop and frisk" law, or to give the police power to detain on suspicion, because of the broad s. 435 arrest power. The choice faced by the police now is to either obtain voluntary cooperation or to arrest. The result is a good many illegal arrests, and subsequent release without charge. Surely the Committee does not really believe, as it seems to imply (p. 57), that the action for false arrest is any check on this practice. ${ }^{16}$ I suggest that it would have been better to recognize the reality of current practice, and to have recommended the narrowing of s. 435 and the passage of a "stop and frisk" provision. ${ }^{17}$ This would have been a better solution than to give sanction to what has become, in effect, a "stop and arrest" law. One does not wonder that the police were unanimous in telling the Committee that the powers of arrest in Canada are adequate.

The Committee finds the degree of force authorized by section 25 of the Code to apprehend a fleeing suspect to be excessive. The combined effect of s. 435 and s. 25 means that with respect to every offence in the Code, a police officer is justified in using force that is intended or is likely to cause death or grievous bodily harm. The Committee takes the position, with which I generally agree, that the use of firearms is only justifiable where the crime is a serious one involving violence. The value of human life ought, in most cases, to be put above the value of apprehending a suspected criminal. I wonder, though, whether the Report's proposals (p. 61) are still not too broad in allowing the use of firearms. Is the taking of an offender's life, or accidentally the life of an innocent bystander, justified in all cases in which a serious crime involving violence has been committed? Would not a single test of a substantial risk of danger to the lives of the public or the police be a narrower, and therefore more justifiable, criterion for the use of guns by the police?

The Committee notes that the rules of a number of Canadian police forces are more restrictive than s. 25 of the Code. Indeed the rules of the Metropolitan Toronto Police require a substantial risk to the lives of the public or the police before guns may be used, yet this force have had a significant number of firearms "incidents" in the past few years in which it has been alleged that no danger to life was involved. In each case the police conduct was cleared by a secret police inquiry, or by the courts after an independent witness had contradicted the official police version 
of the incident. This suggests that rules alone, whether in a police manual or in a criminal code, are not enough to govern police behaviour. Some visible internal/external check on police conduct, with a subsequent setting of standards that are enforced through meaningful job sanctions, and the insurance of feedback to the individual constable, is required. Of course, this was not to be dealt with as it is a matter of internal police structure.

The Committee's sections on search (pp. 61-7) are very cursory and contain no recommendations other than one for codification of police powers. However, after noting that the law is uncertain in this area, no attempt is made to set out what these powers should be other than that blood wihdrawal or stomach pumps should be prohibited without the consent of the accused. With respect to search of premises, there is no analysis of the adequacy, use, or misuse of s. 429 of the Code. Without an exclusionary rule, there is almost no judicial check on the issue or execution of search warrants in Canada. It is often alleged that warrants are too readily issued under s. 429 , and that, once issued, are often used to conduct a general search. The Committee would have provided a useful service if it had done some research in this area in an attempt to arrive at the truth of the matter. Instead we are treated to a three paragraph analysis of some recent United States cases to show (for what reason is not clear to me) that the powers of search here are broader than they are in the United States. As to writs of assistance, those open-ended search warrants that have been virtually unheard of in England since the Court of Star Chamber, or in the United States since the revolution, the Committee states that

it does not appear that the broad powers conferred by the granting of these writs has been abused...

Why it does not appear we are not told. In 1962, the Minister of Justice stated that there were 2,047 writs then current. Is this the case today? If so, what is the need for such a large number of outstanding writs? The essential question as to why these extraordinary writs are needed at all is never asked. The Committee does note that they are used only in areas of

vital public interest, namely, the protection of the revenue and the suppression of traffic in narcotic drugs. (p. 67).

Out of considerations of space, and mercy to the Committee, I shall refrain from commenting on that observation.

The Committee's recommendations on the admissibility of illegally obtained evidence are a step in the right direction. I agree that an inflexible rule of absolute exclusion is neither necessary nor desirable. I prefer, however, the Scots rule which, as I read the leading case of Laurie $v$. Muir, ${ }^{18}$ requires the police conduct to be excused before the evidence will 
be admitted. It may be that in practice the Committee's formulation ( $p$. 74) will come to this, but I think it would be better to cast the legislation in terms of the police having to account for their failure to comply with the law. This is made all the more necessary by the Committee's failure to recognize the abuses inherent in sections 429 and 435 of the Code, and to recommend changes. Once again, however, the matter is not just one of rules, but is as much one of the proper governance of a complex administrative bureaucracy.

The Committee's section on the official instigation of crime and the defence of entrapment is typical of the type of platitude, and refusal to ask and seek answers to difficult questions, that characterizes almost all of chapter 5. The result is a recommendation that at first glance seems reasonable and worthy of support, but on second consideration is seen to be inadequate. The Committee cites with approval the Saskatchewan case of Amsden v. Rogers ${ }^{19}$ in which Mr. Justice Lamont indicated that it was proper for the police to resort to pretence to obtain evidence

in cases where crimes have been committed

but quite improper to do so

for the purpose of inducing its commission.

The Committee then says

that Parliament should declare that the police of the criminal law is opposed to the instigation by public officials of persons, who might otherwise have obeyed the law, to commit offences ... (p. 78)

The difficult question in this is, how does one judge whether the person in question might otherwise have obeyed the law?

Specifically, the Report recommends that instigation by a police officer be a defence if the accused

did not have a pre-existing intention to commit the offence.

Will pre-existing intention be proved by the admission of evidence concerning the accused's reputation and prior convictions? If so, will the court not really be involved in trying a man for his past conduct? Most importantly, entrapment is used most often in crimes that involve a high degree of human weakness - narcotics, liquor, gambling and prostitution. Should the law play the temptress in these consensual crimes, particularly when the slightest temptation may result in the commission of the offence and thus provide evidence of the "pre-existing intention". As to all of these difficult questions, there is not a hint in the Committee's work. Another important policy question that is not adverted to is that of police practices. The defence ought not to be seen only as a protection for an accused who might otherwise not have committed the crime. It should also be seen as a judicial check on official conduct, and the defence should be drafted so as to emphasize this point. Of course before considering any 
legislation one would like the answers to such questions as whether encouragement is a necessary detection technique; if so, for what crimes; and is encouragement a proper function of the state with respect to these crimes. In other words, how extensive is the policy practice, is it necessary, and is it sound criminal law policy? These are all questions the Committee should have, but did not ask. ${ }^{20}$

Chapter 5 concludes with a section on electronic surveillance. As a Parliamentary Committee has just finished an extensive inquiry into the subject, and as the Minister of Justice has outlined the proposed legislation, it is doubtful that the Report's proposals will have much influence. Nonetheless, I shall examine them briefly. The Committee recommends that electronic surveillance be placed under legal control and follows the provisions of the United States "Omnibus Crime Control and Safe Streets Act" closely (pp. 84-85). I think this is good legislation and we would do well to be guided by it. The Committee Report seems to imply, however, that under the United States legislation, the tapes are only supplied to a person when he has been charged with an offence. This is not the case. Any person who has had his conversations recorded must be informed of that fact and is entitled to a copy of the tapes. This is an important provision, as no search by the state, regardless of the type, should ever be hidden from the person searched.

The Committee suggests that a warrant to eavesdrop should be granted only by a superior court judge. This is the American solution, and is one of the most controversial points in all the proposed legislative solutions to the problem. In a previous article, ${ }^{21} \mathrm{I}$ suggested that a combination of the British and American legislation might provide the best safeguard against an easy, if not automatic, grant of such warrants; that is the chief constable, or a designated officer, would have to apply to the provincial attorney-general. If the attorney-general passed on the application, he would then seek a warrant from the chief justice of the trial division. I considered that such a formalized procedure might ensure that such warrants would be neither lightly sought, nor granted. It appears that the Minister of Justice is considering legislation that would make him the sole grantor of the warrant. This may be the best solution of all, particularly when combined with a detailed annual report by him to Parliament. If this proposal does not turn out to be politically feasible, and I doubt that it will, then either the Minister of Justice, or the provincial attorneygeneral (I prefer the single federal official) should apply to the chief justice of the appropriate trial division. I think the least desirable solution is the police or crown application directly to a superior court judge.

I agree wholeheartedly with the Committee's recommendation that a conversation recorded through an unlawful wiretap, or other evidence obtained as a result of such a wiretap, should not be admissible in court, and the legislation should so provide. As the Committee puts it 
It is difficult to envisage an illegal wiretap occurring through error or inadvertence.

It has been reported that the Parliamentary Committee will recommend that such evidence should be admissible, apparently on the theory that evidence of a crime ought not to be suppressed, regardless of how it is obtained. About all one can say in reply is to repeat the old, but nonetheless true, adage that there are values in our system of justice that transcend the conviction of a criminal.

One point in this section that I find particularly worrisome is the Committee's attitude toward matters of national security. It takes a "hands-off" approach and says that national security is a matter

within the sphere of the executive branch of government.

This attitude will likely be reflected in the federal government's legislative proposals later this year. We Canadians have always taken an unquestioning attitude whenever the government has raised the spectre of national security. It is time for a little light to be shed on this murky area of official activity, and for the processes to made subject to the demands of due process. What groups constitute a threat to our security that they must be kept under surveillance, and who is to make such judgments? Does the Parti Quebecois, or the Canadian Communist Party, or the Canadian Nazi Party, or the Students for a Democratic Society, or perhaps the Canadian Council for Fair Taxation qualify? There is little need for special rules with respect to official activity in the national security area. A single exception may be in the reporting procedure for surveillance concerned with espionage, and even then espionage should be carefully defined.

The Committee concludes Chapter 5 with the opinion that police powers in Canada are adequate but not excessive, and that increases are not justified at this time. Rather it proposes the usual nostrums to upgrade the police forces and increase their efficiency - efficiency being the primary value. These include better pay, better working conditions, better training, better equipment, elimination of small forces, central communication systems, and uniform and better systems for reporting crime. All of these are desirable, and will probably all come to pass. But do they relate to the central problems of law and order in the 1970's? Will they help to cope with the problem of the proper governance of our police forces; with the proper relationship between the police, the public, and government; with the proper functions of a police force today; with the proper stance of the police towards social disorder; with the proper relationship between the police, the prosecution, and the courts; and with the role of the courts in the administration of criminal justice? I suggest they do not. The tragedy of the Report is that the "job" is now done for another decade and we will have to wait for another commission, or task force, or hopefully some independently sponsored research, to provide 
us with the answers to these vital questions. Meanwhile we can indulge in the usual Canadian luxury of being satisfied that, unlike our American neighbours, we do not yet have a crisis in our social order and in the administration of criminal law.

\section{FOOTNOTES}

1. Report of the Canadian Committee on Corrections. Ottawa: Queen's Printer, 1969 , p. 39.

2. Ibid, p. 43.

3. I have borrowed heavily here from Lehman, "Crime, the Public, and the Crime Commission: A Critical Review" of The Challenge of Crime in a Free Society (1968), 66 Michigan L. Rev. 1487, 1520-26.

4. Report of the Canadian Committee on Corrections. Ottawa: Queen's Printer, 1969 , p. 44.

5. To be fair, it should be noted that the works of Wilson, LaFave, Skolnick and others are all cited in Chapter 5. If they were read, the results of their research were either rejected, or simply not considered.

6. For an excellent analysis of the problem see Goldstein, "Administrative Problems in Controlling the Exercise of Police Authority", (1967) $58 \mathrm{~J}$. of Cr. L. Crim and P.S., 160.

6a. See Wilson, Varieties of Police Behavior (Harvard, 1968), pp. 64-78.

7. (1954) 13 W.W.R. 398, 20 C.R. 37.

8. 128 C.C.C. 213.

9. (1969) 68 W.W.R. 163.

10. [1956] S.C.R. 958

11. (1949), 94 C.C.C. 1.

12. (1968) 65 W.W.R. 549.

13. [1964] 2 C.C.C. 305.

14. Declercq v. The Queen, 70 D.L.R. (2d) 532.

15. "Driver, Confessions and the Social Psychology of Coercion", (1968) 82 Harv. L. Rev. 42.

16. The American Law Institute's Model Code of Pre-Arraignment Procedure contains a good draft "stop and frisk" provision. See Tentative Draft No. 1, 1966 at pp. 95-97 for a discussion of the subject.

17. For an analysis of the arrest problem see Weiler, The Control of Police Arrest Practices: Reflections of A Tort Lawyer, in Linden, Studies in Tort Law (1968), p. 416.

18. [1950] S.C. (J) 19.

19. (1916) 26 C.C.C. 389.

20. See Rotenberg, The Police Detection Practice of Encouragement, (1963) 49 Virginia L. Rev. 871.

21. Beck, Stanley. "Electronic Surveillance and the Administration of Criminal Justice", (1969) 46 Can. Bar Rev. 643. 